\title{
Genetic diversity of recombinant inbred lines of Phaseolus vulgaris L. ${ }^{1}$
}

\author{
Diversidade genética de linhagens endogâmicas recombinantes de Phaseolus vulgaris L.
}

\author{
Lidiane dos Santos Gomes Oliveira ${ }^{2 *}$, Leandro Pin Dalvi ${ }^{2}$, Lucimara Cruz de Souza ${ }^{2}$, Josimar Aleixo da Silva ${ }^{2}$ \\ and Tais Cristina Bastos Soares ${ }^{2}$
}

\begin{abstract}
Considred a more accessible protein source for the population, common beans are consumed daily, mainly in developing countries, in the tropical and subtropical regions of the planet. Studies that use both morphological descriptors and molecular markers have been used in plant breeding programs for common beans. This article aims to report the study of the diversity of recombinant inbred lines and their parents using morphologial descriptors and SSR markers. 22 recombinant inbreeding lines were evaluated derived from the BRS Agreste parents and the black-01 line.For the characterization, 18 microsatellite markers and the following morphological descriptors were used: presence of anthocyanin, number of days after germination, days for flowering, wing color, standard color, seed color, tegument color, seed brightness, commercial group. For molecular characterization, seven markers were used that presented polymorphism The dissimilarity values, using morphological data, ranged from 0 to 8.5 ; organizing the lineages into three distinct groups. In the molecular analyzes, of the 18 primers tested, 11 were monomorphic and 7 presented polymorphism. The dissimilarity values for molecular analysis ranged from 0 to 0.8 ; with an average of 0.57 . In addition to being informative, these markers are associated with important characteristics for common beans. Joint analysis of the data presented dissimilarity values ranging from 0.0 to 12.5 , with an average of 6.89 , forming three groups. The joint analysis of morphological and molecular data was efficient to characterize and distinguish inbred lines. The molecular markers used were suitable to the present study. The lines 18 and 19 can be considered duplicate because in all analyzes they remained together.
\end{abstract}

Key words: Dissimilarity. Common Bean. SSR Marker. Genetic improvement. SSD.

RESUMO - Considerado fonte de proteína mais acessível à população, o feijão-comum é consumido diariamente, principalmente nos países em desenvolvimento, das regiões tropicais e subtropicais do planeta. Estudos que utilizam tanto descritores morfológicos quanto marcadores moleculares, vêm sendo utilizados em programas de melhoramento vegetal do feijoeiro. O presente artigo tem por objetivo reportar o estudo da diversidade de linhagens endogâmicas recombinantes e seus genitores utilizando descritores morfológicos e marcadores SSR. Foram avaliadas 22 linhagens recombinantes derivadas dos genitores BRS Agreste e a linhagem preto-01. Para a caracterização foram utilizados 18 marcadores microssatélites e os seguintes descritores morfológicos: presença de antocianina, número de dias após a germinação, dias para floração, cor da asa, cor do estandarte, cor da semente, cor do tegumento, brilho da semente, grupo comercial. Para caracterização molecular foram usados sete marcadores que apresentaram polimorfismo. Os valores de dissimilaridade, utilizando-se os dados morfológicos, variaram de 0 a 8.5 ; organizando as linhagens em três grupos distintos. Nas análises moleculares, dos 18 primers testados, 11 foram monomórficos e 7 apresentaram-se polimorfismo. Os valores de dissimilaridade para análise molecular variarando de 0 a 0.8 ; com média de 0.57. Além de informativos, esses marcadores estão associados a características importantes para o feijoeiro. A análise conjunta dos dados apresentou valores de dissimilaridade variando de 0.0 a 12.5 , com média de 6.89 , formando três grupos. A análise conjunta dos dados morfológicos e moleculares foi eficiente em caracterizar e distinguir as linhagens endogâmicas. Os marcadores moleculares utilizados mostraram-se adequados para o estudo realizado neste trabalho. As linhagens 18 e 19 podem ser consideradas duplicadas, pois na análise de diversidade obteve dissimilaridade zero.

Palavras-chave: Dissimilaridade. Feijão-comum. Marcador SSR. Melhoramento genético. SSD.

DOI: $10.5935 / 1806-6690.20210033$

Editor do artigo: Professor Josué Silva - josue.bispo@hotmail.com

*Author for correspondence

Received for publication in 07/04/2020; approved in 14/09/2020

'Parte da Tese do primeiro autor apresentada ao Curso de Pós-Graduação em Genética e Melhoramento, Universidade Federal do Espírito Santo 2Programa de Pós-Graduação em Genética e Melhoramento, Universidade Federal do Espírito Santo, Alegre-ES, Brasil, lidianegomes31@gmail.com (ORCID ID 0000-0003-1245-7633), leandropin@yahoo.com.br (ORCID ID 0000-0002-2995-8007), lucimaracruz15@hotmail.com (ORCID ID 0000-0001-5795-7960), josimaraleixo_@hotmail.com (ORCID ID 0000-0001-6921-6043), tcbsoares@gmail.com (ORCID ID 0000-0001-6356-7993) 


\section{INTRODUCTION}

Widely cultivated and consumed all over the world, common beans (Phaseolus vulgaris L.), is one of the most important plants in human nutrition, its consumption is increasing every year worldwide, mainly due to the aspect of health promotion, as it is considered as a healthy product that helps prevent some diseases (ANJOS, 2017). With world production of 26.8 million tons, and an area harvested of 29.4 million hectares, the largest world producers of beans are Myanmar, India, Brazil, United States, Tanzania and Mexico, producing 12.7 million tons. In the international market, the main exporting countries are China, Myanmar and the USA and the largest importers are India and the European Union (FOOD AND AGRICULTURE ORGANIZATION OF THE UNITED NATIONS, 2018).

Common beans are an annual diploid species $(2 \mathrm{n}=2 \mathrm{x}=22)$, predominantly autogamous with crossfertilization rates of approximately $3 \%$. Domesticated for more than 7,000 years in two main centers of origin, a Mesoamerican that covers Mexico and Central America, and an Andean (gene pools) (FISSEHA et al., 2016; GEPTS et al. 1986), in addition to several secondary domestication centers. This fact contributed to the wide genetic and phenotypic diversity of the species, resulting in a huge variety of colors, textures and grain sizes (SINGH; GEPTS; DEBOUCK, 1991).

Knowledge about genetic diversity and its distribution in a species is useful for germplasm conservation and identification of genetic materials with interested characteristics to be included in breeding programs (FERRÃO et al., 2016). The morphological characterizations are little influenced by the environment, as they are qualitative, which has its limitations, since the evaluations are based on phenotypic characteristics such as flower color, growth habit, seed brightness, etc., in addition to focusing mainly on the traditional identification of evolutionary and lineage relationships. Molecular genetic analyzes, on the other hand, are independent of the effect of the environment, are more informative and are widely available for the characterization of genetic materials, as they are performed with DNA markers. The genetic diversity in bean has been studied through morphological characterization combined with molecular markers, being a complementary tool to morphological evaluations (CRUZ; FERREIRA; PESSONI, 2011).

There are a variety of molecular markers available of different types of genetic studies. Microsatellites (SSRs - Simple Repetitive Sequences) are one of the most polymorphic classes of molecular markers, they are genomic and composed by repeated single sequences of two to five nucleotides in a DNA sequence (VIEIRA et al., 2016). Based on PCR and codominant, these characteristics make these markers efficient tools for genetic diversity studies, and it is possible to obtain greater amount of genetic information compared to dominant markers (ANDRADE et al., 2013; NADEEM et al., 2018).

Studies about genetic diversity becomes important in a breeding program by providing parameters for parental lines identification enabling a larger heterotic effect and a greater segregation in recombinants, Existence of genetic variation for all character of economic importanc increases probability of identifying superior genotypes in the progenies (CABRAL et al., 2018).

In view of the foregoing, the study aimed to evaluate the diversity morfoagronomic and molecular of 22 recombinant inbred lines and their parents, belonging to the collection of Plant Analysis Laboratory from Plant Production Department of the Agricultural Sciences Center and Engineering from Federal University of Espírito Santo.

\section{MATERIAL AND METHODS}

\section{Genetic Material}

The genotypes used consisted of 22 recombinant inbreeding lines of bean (generation F8), and their parents. The crossings occurred in a greenhouse in 2014, between the cultivar BRS Agreste, used as a female parent, developed by Empresa Brasileira de Pesquisa Agropecuária -EMBRAPA and the black-01 line used as male parents from the collection of Plant Analysis Lab from Agronomy Department (Table 1). A sample of F2 seeds was advanced to F8 generation, in a greenhouse, using SSD method (BRIM, 1966), with some modifications. By this method, one pod was harvested from each F2 plant to constitute generation F3. This procedure was repeated until generation F8. In generation F8, there were a total of 22 recombinant inbred lines and their parents; the selection was performed in each generation advance. In order to obtain DNA, the sowing was performed in a greenhouse.

\section{DNA extraction}

DNA was extracted from young, fully expanded and healthy leaves according to the CTAB method (cetyltrimethyiammonium bromide) described by Doyle and Doyle (1990), with the following modifications: the extraction buffer used was 2\% CTAB, $100 \mathrm{mM}$ Tris- HCL $\mathrm{pH}$ 8.0, 1.4 M NaCl, $20 \mathrm{mM}$ EDTA pH 8.0, 1\% PVP and 0.2\% $\beta$-mercaptoethanol. The integrity, concentration and purity of DNA samples were verified by spectrophotometry on NanoDrop ${ }^{\circledR}$ instrument (Thermo Scientifc 2000C).

Primer amplification reactions were performed in a final volume of $15 \mu \mathrm{L}$ containing $\mathrm{MgCl}_{2}(2.4 \mathrm{mM})$, Tris- $\mathrm{KCl}$, 
pH $8.3(0.25 \mathrm{mM})$, dNTP (0.25 mM of each nucleotide), 0.6 $\mu \mathrm{M}$ of each primer, $1 \mathrm{U}$ Taq polymerase and $30 \mathrm{ng}$ of DNA. The amplifications were performed in Applied Biosystem Thermal Cycler, model Veriti ${ }^{\circledR}$, programmed as follows: an initial step of five minutes at $94^{\circ} \mathrm{C}$ and 30 cycles consisting of: one minute at $94{ }^{\circ} \mathrm{C}$, one minute at $50{ }^{\circ} \mathrm{C}$ and two minutes at $72^{\circ} \mathrm{C}$, and a final ten-minute step at $72^{\circ} \mathrm{C}$. For primers with two annealing temperatures, only the cycles were changed, nine cycles at $94^{\circ} \mathrm{C}, 58^{\circ} \mathrm{C}$ and $72{ }^{\circ} \mathrm{C}$ during 20 seconds in each temperature and 25 cycles at $94{ }^{\circ} \mathrm{C}, 60{ }^{\circ} \mathrm{C}$ and $72{ }^{\circ} \mathrm{C}$ during twenty seconds at each temperature, respectively. The amplified microsatellite fragments were separated in a $10 \%$ polyacrylamide gel electrophoresis at 100 volts, for about three hours. After run, the gels were photographed under ultraviolet light using a photographic documentation system.

\section{Data analysis}

Twenty-six bean characters were evaluated in a greenhouse, indicated by the Minimum Descriptors list, according to the Decree 2366/97 (BRASIL, 1997). Only characters that showed polymorphism were used in the analyzes: anthocyanin presence (analyzed in seedling stage), number of days to after germination, days to for flowering $(50 \%$ of plants in flowering stage), wing color (during flowering), standard color (during flowering), seed color (after harvest), seed coat color (after harvest), seed brightness (after harvest), commercial group (after harvest).

Molecular analyzes were selected 18 SSR markers for common bean crop (BLAIR; IRIARTE; BEEBE, 2006; GAITÁN-SOLÍS et al., 2002) and the selection criteria were the largest number of polymorphism and, location of SSR in the linkage groups of common bean consensus map (YU et al., 2000) to achieve greater genome coverage. The selected markers were initially tested in the parents and, those that showed polymorphic were selected to genotype the parents (Table 2). Descriptive analyzes of genetic diversity were performed, and estimates of expected heterozygosity $(\mathrm{He})$; observed heterozygosity $(\mathrm{Ho})$; analysis of each allele/locus and polymorphic information content (PIC) were obtained.

Table 1 - Morphological characteristics of parents genotypes from common bean crop collection of Agronomy Department (CCAE-UFES,2017)

\begin{tabular}{lccccccccc}
\hline Genotypes & Paca & Dae & DF & Wing color & Standard color & Seed color & Coat Color & Seed brightness & Commercial classes \\
\hline BRS Agreste $(+))$ & Absent & 33 & 38 & White & White & Beige & Beige & Opaque & Others \\
Preto-01 $(\hat{O})$ & Present & 32 & 36 & Purple & Purple & Black & Beige & Intermediary & Black \\
\hline
\end{tabular}

*PACA $=$ Presence of anthocyanin in the stem; DAE= Days After Emergency; DF= Days for flowering

Table 2 - SSR primers used, base sequence, annealing temperature (Tm) and bonding group

\begin{tabular}{|c|c|c|c|}
\hline Primer & Sequence in the direction $5{ }^{\prime} 3^{\prime}$ & $\mathrm{At}^{1}\left({ }^{\circ} \mathrm{C}\right)$ & $\mathrm{GL}^{3}$ \\
\hline \multirow{2}{*}{ PV-ctt001 } & F GAGGGTGTTTCACTATTGTCACTGC & \multirow{2}{*}{48} & \multirow{2}{*}{ B04 } \\
\hline & R TTCATGGATGGTGGAGGAACAG & & \\
\hline \multirow{2}{*}{ PV-ag004 } & F $\quad$ TTGATGACGTGGATGCATTGC & \multirow{2}{*}{48} & \multirow{2}{*}{$\mathrm{U}^{4}$} \\
\hline & R AAAGGGCTAGGGAGAGTAAGTTGG & & \\
\hline \multirow{2}{*}{ PV-gaat001 } & F CACGGTACACGAAACCATGCTATC & \multirow{2}{*}{$58 / 60^{2}$} & \multirow{2}{*}{ B04 } \\
\hline & R AAGGATGGGTTCCGTGCTTG & & \\
\hline \multirow{2}{*}{ BM139 } & F TTA GCA ATA CCG CCA TGA GAG & \multirow{2}{*}{$58 / 60^{2}$} & \multirow{2}{*}{ B02 } \\
\hline & R ACT GTA GCT CAA ACA GGG CAC & & \\
\hline \multirow{2}{*}{ BM142 } & $\begin{array}{ll}\text { F } & \text { TTCCGCTGATTGGATATTAGAG }\end{array}$ & \multirow{2}{*}{50} & \multirow{2}{*}{ B02 } \\
\hline & R AGCCCGTTCCTTCGTTTAG & & \\
\hline \multirow{2}{*}{ BM 187} & F TTТCТССААСТСАСТССТТТСС & \multirow{2}{*}{50} & \multirow{2}{*}{ B06 } \\
\hline & R TGTGTTTGTGTTCCGAATTATGA & & \\
\hline \multirow{2}{*}{ BM185 } & F AAGGAGGTTTCTACCTAATTCC & \multirow{2}{*}{50} & \multirow{2}{*}{ B08 } \\
\hline & R AAAGCAGGGATGTAGTTGC & & \\
\hline
\end{tabular}

${ }^{1}$ Annealing temperature do primer; ${ }^{2}$ Cycle temperature 1 and cycle 2 annealing of primers; ${ }^{3}$ link group; ${ }^{4}$ Off 
Joint analyzes of qualitative and quantitative characters data with molecular characters were performed using genetic distances, and employed in cluster analysis using the method of average linkage among groups (UPGMA). All genetic distances were estimated by Gower algorithm (1971), and employed in cluster analysis by average linkage among groups (UPGMA).

The cutting point $(\mathrm{Pc})$ to determine the number of groups formed in the dendrogram was established by statistical criterion proposed by Mojena (1977). The cophenetic correlation coefficient (CCC) was estimated in order to verify the reliability of the data and the grouping consistency, that is, the fit among original dissimilarities measures and those graphically generated (SOKAL; ROHLF, 1962). For all data analysis, the Genes software was used (CRUZ, 2017).

\section{RESULT AND DISCUSSION}

The clusteranalysis of morphological characteristics separated the 22 lines and their parents into three groups (Figure 1), with $\mathrm{k}=1.25$, and $54.79 \%$ cutting point was established. The cluster consistency verified by cophenetic correlation coefficient was $85.5 \%(\mathrm{CCC}=0.855)$. The cophenetic correlation coefficient showed reliability in the relationship between dissimilarity matrix and dendrogram generated by UPGMA. Values of CCC above 0.8 indicate good representativeness among distances. Silva and Dias (2013) comparing different grouping methods, found that the cophenetic correlation coefficient by the UPGMA method showed better consistency, as well as Cargnelutti Filho, Ribeiro and Burin (2010) studying clustering in bean cultivars verified that UPGMA method presents greater consistency of the grouping pattern, obtained from dissimilarity matrix.

The dissimilarity values ranged from 0.0 to 8.5 , with an average of 4.29 . The shortest genetic distance was between the pairs of strains L1 x L8 and L1x L9. Lines L4 and L7 showed the greatest distances with lines L22, L23 and L24, followed by L5 with lines L18 and L19, showing genetic variability between lines. The descriptors used did not allow the distinction of the pairs of lines L4 x L7, L1 x L8, L1x L9, L18 x L19, L22x L23, L23 x L24, all presented null values of dissimilarity In addition, these pairs of lines showed the same genetic distance in relation to the parents (Table 3), which indicates that these materials are duplicates. From dissimilarity measurements, a dendrogram was designed with morphological characteristics (Figure 1). The dendrogram allocated lines in three distinct groups, with number of lines ranging from 12 to 05 lines per group. For this analysis, the data showed genetic divergence among lines from formed groups.

Characteristics such as anthocyanin, commercial group and grain color were important to form groups. Group G1 presented individuals from black commercial group with similar characteristics with male parent $($ ふ $)$ and Groups G2 and G3 were formed by commercial classes lines, others and mulatto, which showed similarities with female parent $(+)$.

Figure 1 - Representative dendrogram of genetic dissimilarity from morphological data, represented by 24 individuals, grouped by UPGMA method, forming three groups. Cutting Point (Cp): $54.79 \%$

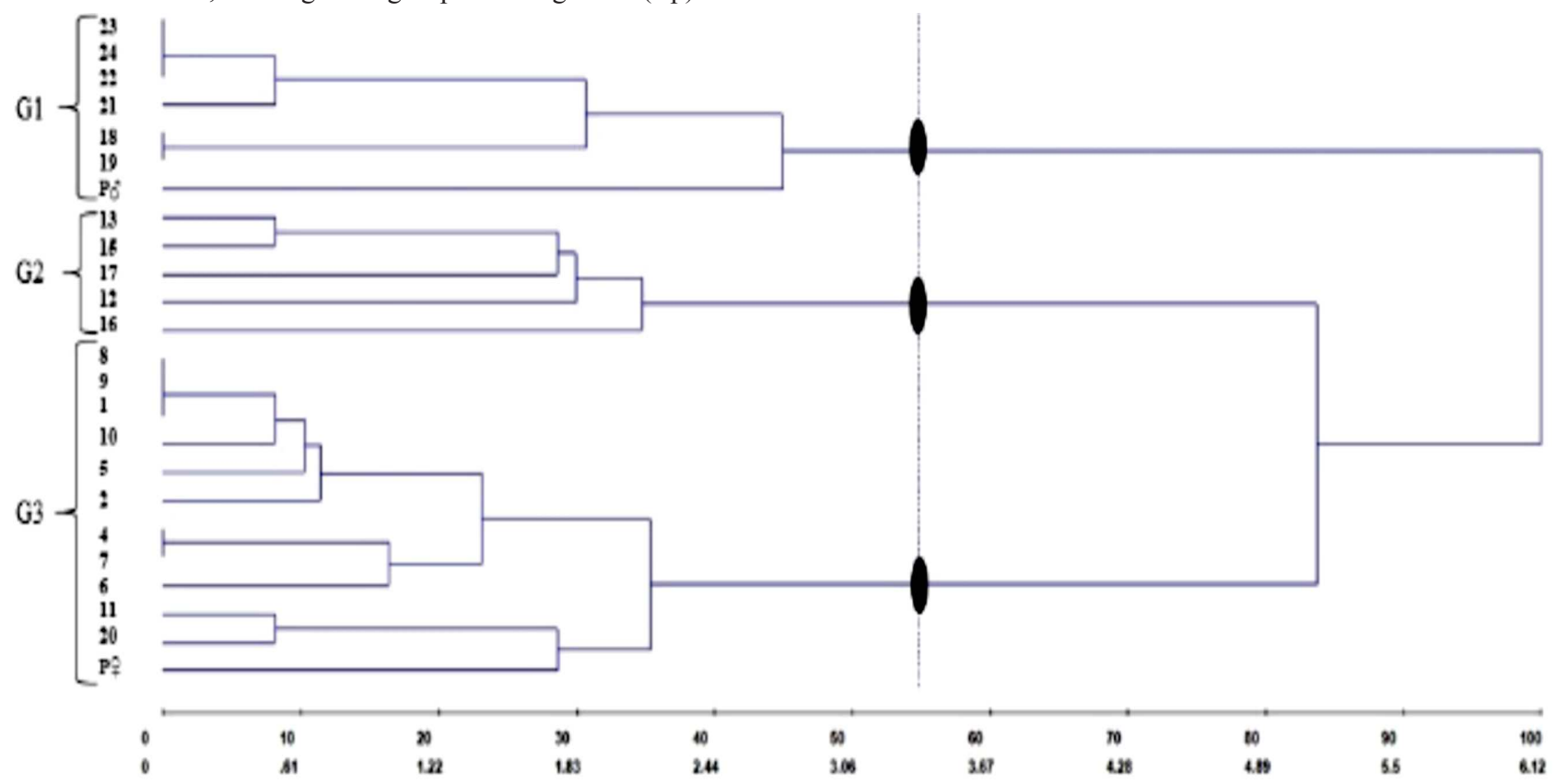


Table 3 - Line distances (duplicates) from parents

\begin{tabular}{|c|c|c|}
\hline \multirow{2}{*}{ Lines } & \multicolumn{2}{|c|}{ Distances } \\
\hline & Parent $(+)$ & Parent $\left(ठ^{\Uparrow}\right)$ \\
\hline L1 & 3 & 5 \\
\hline L4 & 2.5 & 6.5 \\
\hline L7 & 2.5 & 6.5 \\
\hline L8 & 3 & 5 \\
\hline L9 & 3 & 5 \\
\hline L18 & 6 & 4 \\
\hline L19 & 6 & 4 \\
\hline L22 & 7 & 2 \\
\hline L23 & 7 & 2 \\
\hline L24 & 7 & 2 \\
\hline
\end{tabular}

The genetic inheritance of presence of anthocyanins in colored beans is predominantly quantitative, with many genes involved, this characteristic can be controlled by the same genes related to seed color pattern. Anthocyanin (coloration) in cotyledons, hypocotyl and stem is found mainly in beans of the black commercial group and also reflects in the purple coloration of flowers (HAYAT et al., 2013), being observed in Group 1, and are the only ones with purple wing and standard.

Specific grain coloration is one of the important characteristic sought by breeders, since there are market preferences in common bean color. In order to attend consumer market, the bean breeding programs search new cultivars with known preferred characteristics, more easily accepted in each producing region.

Plants with violet flowers, present black grains and plants with white flowers present light colors grains. Due to epistatic effects, proving to be an important characteristic to form groups. The data obtained by agronomic evaluation and morphological characterization of lines are of great importance to identify genetic variability among them. Considering molecular analyzes, among primers tested for parents, 11 were monomorphic and 7 were polymorphic; thus the primers polymorphic were, therefore, used to amplify the DNA extracted from progeny. In addition, there was good genome coverage, since the selected primers belong to different linkage groups $\left(\mathrm{B} 04, \mathrm{U}^{4}, \mathrm{~B} 02\right.$, B06 and B08) of the common bean binding map.

The molecular markers SSRs used in this study were efficient to detect polymorphism in the inbred lines, showing genetic variability among them. Therefore, these molecular markers could be considered complementary tools that provide a more complete understanding of the diversity available in common beans.
Graphical representation of the clustering obtained by UPGMA method for molecular data showed presence of three groups (Figure 2). The cutting point $61.63 \%$ was established, with $\mathrm{k}=1.25$. The cluster consistency verified by cophenetic correlation coefficient was $86.03 \%(\mathrm{CCC}=0.8603)$.

The dissimilarity values ranged from 0 to 0.8 , with average of 0.57 , with shortest genetic distances evidenced between L15 with L18 and L19 (0.0) and largest distance between L4 with L10 (0.8). The dendogram(Figure 2) presents three divergent groups. Two of these groups, were formed by only one individual; however, they show great dissimilarity regarding other lines. Group 1 allocated 22 lines, with largest distance found within group between the parents $(0.5)$.

Molecular and morphological analyzes differed in the way they grouped the progenies. In the morphological ones, the progenies were separated in different groups and in the molecular all of them grouped together, in one unique group. However the molecular markers were able to delect differences between lines 10 and 11, which despite having morphological similares.

It shows that diversity estimates based exclusively on morphological or on molecular descriptors can be not enough to separate lines according to characteristics of their parents.

The number of alleles/locus ranged from 2 (for primers PV-ag004, PV-gaat001, BM139, BM142, BM 187, BM 185) to 3 (for primer PV-ctt001) alleles (Figure 3). The primer PV-gaat001 presented $41 \%$ of allele 1 and $8 \%$ of allele 2 , while primer BM142 presented $40 \%$ of allele 2 and $9 \%$ of allele 1 . For the primer with three alleles, PV-ctt001 presented $27 \%$ of allele $1,20 \%$ of allele 2 and $2 \%$ of allele 3 . The PIC values ranged from 0.81 (PV-gaat001) to 0.87 (PVctt001) with an average of 0.85 (Table 4 ). 
Figure 2 - Representive dendrogram of genetic dissimilarity of the molecular data, represented by 24 individuals, grouped by UPGMA method, forming three groups. Cutting Point (Cp): 61.63\%

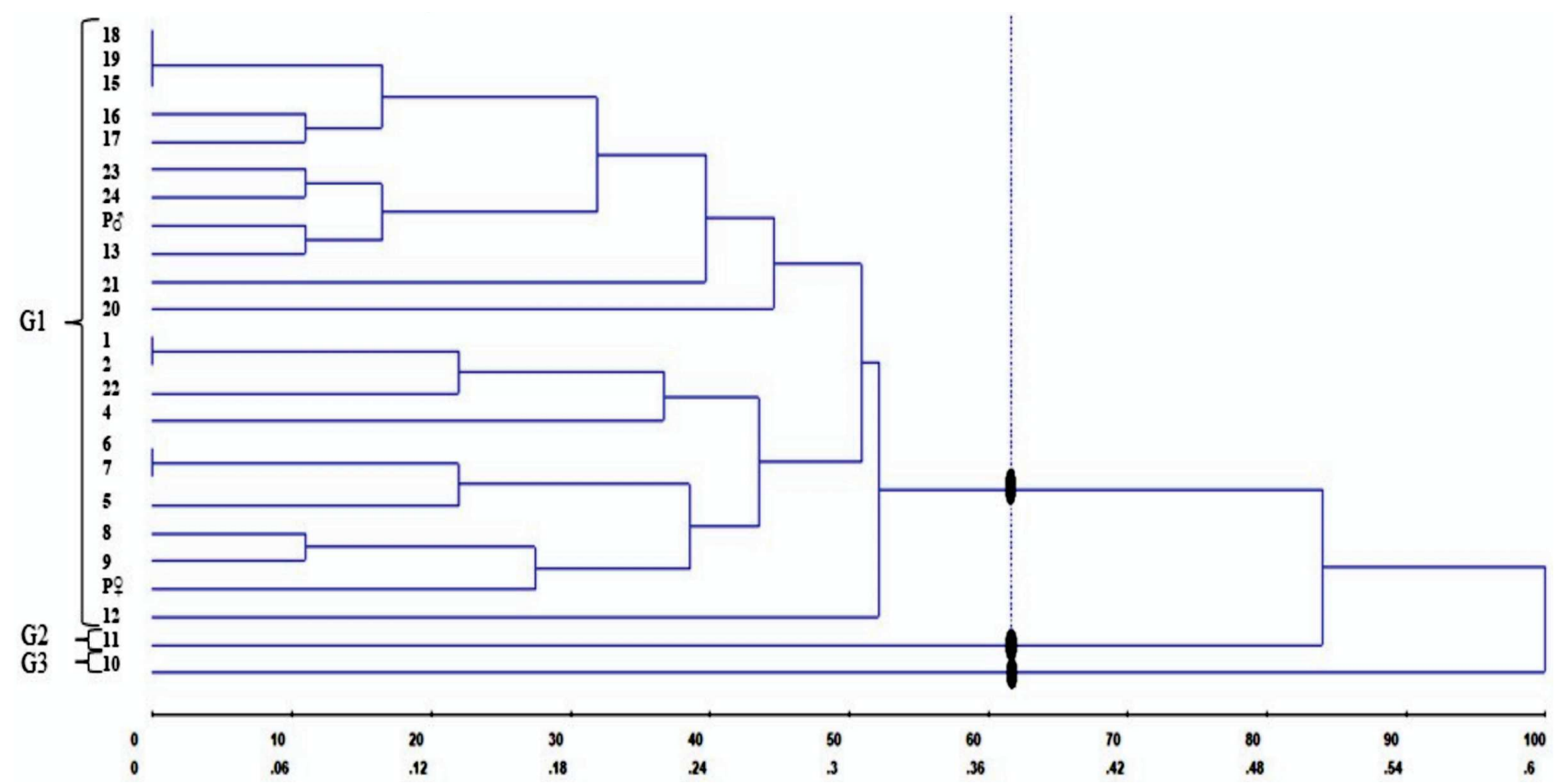

Table 4 - Descriptive analysis of the seven microsatellite loci used in the bean inbred lines

\begin{tabular}{lcccccc}
\hline Loci & $\mathrm{A}_{1}$ & $\mathrm{~A}_{2}$ & $\mathrm{~A}_{3}$ & $\mathrm{H}_{\mathrm{e}}$ & $\mathrm{H}_{\mathrm{o}}$ & Pic \\
\hline PV-ctt001 & 0.27 & 0.20 & 0.022 & 0.88 & 1 & 0.87 \\
PV-ag004 & 0.31 & 0.18 & - & 0.86 & 1 & 0.86 \\
PV-gaat001 & 0.41 & 0.08 & - & 0.81 & 1 & 0.81 \\
BM139 & 0.30 & 0.20 & - & 0.87 & 1 & 0.86 \\
BM142 & 0.09 & 0.40 & - & 0.82 & 1 & 0.82 \\
BM 187 & 0.28 & 0.21 & - & 0.87 & 1 & 0.86 \\
BM 185 & 0.31 & 0.18 & - & 0.86 & 1 & 0.86 \\
Average & - & - & - & 0.85 & 1 & 0.85 \\
\hline
\end{tabular}

* $\mathrm{A}_{1}, \mathrm{~A}_{2}, \mathrm{~A}_{3}$ : Allele frequency; Expected heterozygosity (He); observed heterozygosity (Ho); Polymorphic Information Content (PIC)

Figure 3 - Fragments resulting from the amplification of genomic DNA of 22 strains and two parents $(\mathrm{P}+$ and $\mathrm{P} \hat{\mathrm{O}})$ of $\mathrm{Phaseolus}$ vulgaris in $10 \%$ polyacrylamide gel, using

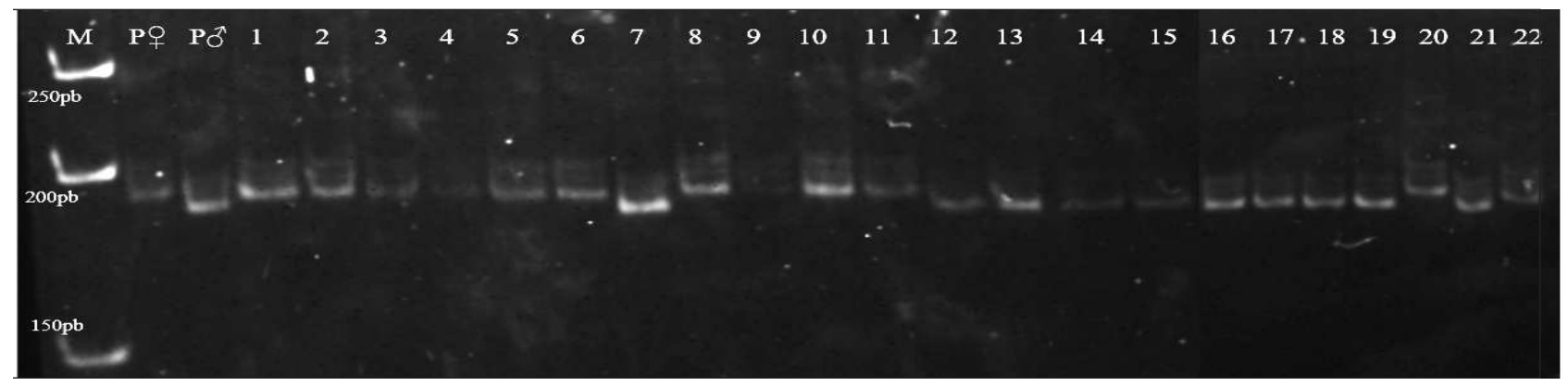

BM 187. M- Molecular weight marker (Ladder 50bp) 
In general, Polymorphic Information Content (PIC) was considered highly informative for the markers under study. The PIC value provides an estimate of marker's discriminatory power by considering the number of alleles per locus, relative frequency of these alleles, and is directly associated to genetic divergence. The PIC indicates the quality of the molecular marker and values below 0.25 refer to little informative markers, from 0.25 to 0.5 moderately informative and higher than 0.5 very informative (BOTSTEIN et al., 1980).

In its turn, primer PV-ctt001 stood out as the most informative of the loci with higher number of alleles. The other primers were also efficient to detect polymorphisms among lines, presenting highly informative PIC values. Besides the efficiency of the markers used in this study, they are associated to important characteristics of bean crop. In addition to the efficiency of the markers used in this study, they are associated with QTLs (Quantitative Trait Loci) important for disease resistance characteristics in the bean culture, thus making them potentially valuable tools to be used in breeding programs and in marker assisted selection (GAITÁN-SOLÍS et al., 2002).

Some used markers are from a conserved genic region in plants and associated to protein-encoding genes, such as primer Pv-gaat001 and, encodes a small subunit of 1,5bisphosphate ribulose, and is linked to a QTL associated to increase resistance to white mold. This marker was initially mapped by Yu et al. (2000), in two populations of inbred bean lines. Another important source of resistance to bean diseases is associated to the marker Pv-ag004. According to Keller et al. (2015), 75.3\% of phenotypic variation of angular spot resistance in common bean is identified by this marker.

The estimated expected heterozygosity $\left(\mathrm{H}_{\mathrm{e}}\right)$ (Table 4) for each locus was lower than observed heterozygosity $\left(\mathrm{H}_{\mathrm{o}}\right)$ in all cases. $\mathrm{H}_{\mathrm{e}}$ ranged from 0.81 to 0.88 , with an average of $0.85 . \mathrm{H}_{\mathrm{o}}$ presented an average of 1 , indicating heterozygosity for all evaluated loci. This indicates a likely cross-pollination at the experimental station, where the experiment took place. Veloso et al. (2015), studying the genetic diversity of bean cultivars, observed that the observed heterozygosity was higher than expected for autogamous plants. It is necessary to consider, however, that in several SSR loci heterozygosis occurs in bean (RODRIGUES; SANTOS, 2006).

When the data were jointly evaluated, the values of dissimilarity ranged from 0.0 to 12.5 , with average of 6.89 , with shortest distance between L18 and L19 lines, and the largest genetic distances between Mother lines with L23 (12.5), L4 and L24 line (12.5) and between L7 and L23 lines (Figure 4).

The joint analysis was efficient to discriminate groups, demonstrating that it is viable and efficient to knowledge the divergence among studied lines. The cutting point established $(\mathrm{K}=1.5)$, was $61.54 \%$, and cophenetic correlation coefficient was $87.84 \%(\mathrm{CCC}=0.8784)$. Three groups were formed, and group 3 comprised $55.5 \%$ of the lines under study, which were mulatto color and another. The Group 1 comprised all black grains together with male parent.

Figure 4 - Representative dendrogram of genetic dissimilarity using molecular and morphhoagronomic data, from 24 common beans lines, grouped by UPGMA method. Cutting Point (Cp): $61.54 \%$

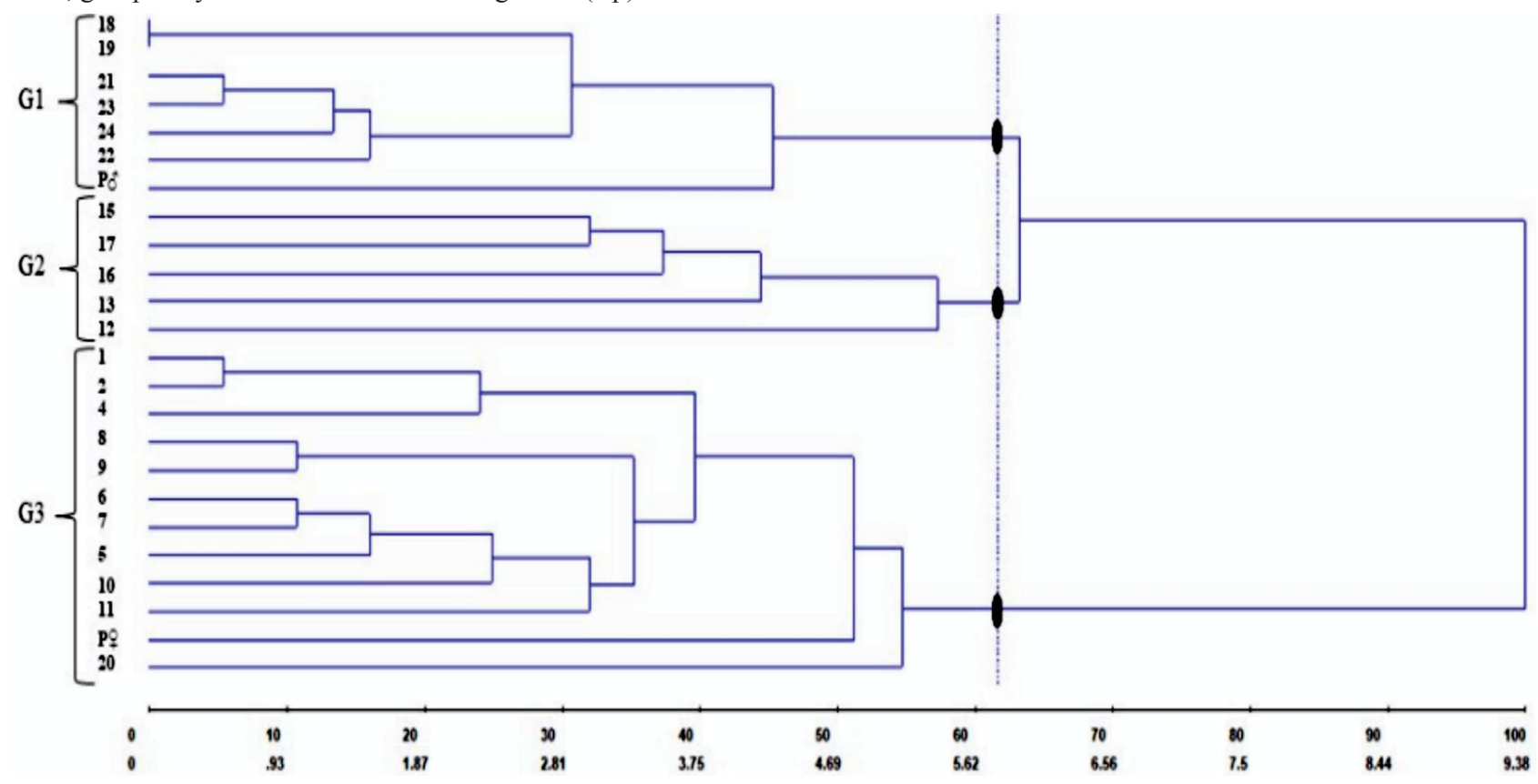


The joint analysis formed the most informative dendograms, regarding distinction of genotypes. The lines L1, L8 and L9 (dissimilarity of 0.0) could not be distinguished based only morphological characters, which indicated as possible identical individuals. The same occurred with the lines L15, L18 and L19 the molecular data analysis. Because of the data association, only the lines L18 and L19 could not be differentiated and are, identified as possible duplicates.

These results indicate that joint data analysis is efficient and contributes to interpret the results, represents a very important auxiliary tool in morphological and molecular characterization studies. It is interesting to point out that, by assembling the morphological and molecular data, all data were distinct from each other, demonstrating not only the relevance of obtaining as much information as possible about lines, but also demonstrating the complementarity effects of these two data groups.

\section{CONCLUSIONS}

1- The joint analysis of the morphological and molecular data was efficient to characterize and distinguish the inbred lines;

2- Lines 18 and 19 can be considered duplicate.

\section{ACKNOWLEDGMENTS}

We would like to thank Coordenação de Aperfeiçoamento de Pessoal de Nível Superior (CAPES) for the financial assistance granted- Finance Code 001. To the Conselho Nacional de Desenvolvimento Científico e Tecnológico (CNPq) for the research granted to T. C. B. Soares ("Bolsa de produtividade em pesquisa"). We thank the Federal University of Espírito Santo and the Program in Genetics and Breeding for providing facilities to develop the research and the Biochemistry and Molecular Biology Laboratory (Bqmol) for the laboratorial support.

\section{REFERENCES}

ANJOS, D. D. N. et al. Avaliação do feijoeiro comum em função dos bioestimulantes, NPK e micronutrientes em Vitória da Conquista - BA. Revista Agrarian, v. 10, n. 35, p. 1-9, 2017.

ANDRADE, M. T. et al. Paternity test for IAPAR 139 cultivar of common bean. Annual Report of the Bean Improvement Cooperative, v. 56, p. 161-162, 2013.
BLAIR, M. W.; IRIARTE, G.; BEEBE, S. QTL analysis of yield traits in an advanced backcross population derived from a cultivatéd Andean wild common bean (Phaseolus vulgaris L.) cross. Theoretical and Applied Genetics, v. 112, n. 6, p. 1149-1163, 2006.

BOTSTEIN, D. et al. Construction of genetic linkage map in man using restriction fragment length polymorphisms. American Journal of Human Genetics, v. 32, n. 3, p. 314-331, 1980.

BRASIL. Decreto-lei n 2.366, de 05 de novembro de 1997. Diário Oficial [da] República Federativa do Brasil, Brasília, 1997.

BRIM, C. A. A modified pedigree method of selection in soybeans. Crop Science, v. 6, p. 220, 1966.

CABRAL, P. D. S. et al. Investigation of the genetic diversity of common bean (Phaseolus vulgaris.) cultivars using molecular markers. Genetics and Molecular Research, v. 17, n. 4, p. 1-11, 2018.

CARGNELUTTI FILHO, A.; RIBEIRO, N. D.; BURIN, C. Consistência do padrão de agrupamento de cultivares de feijão conforme medidas de dissimilaridade e métodos de agrupamento. Pesquisa Agropecuária Brasileira, v. 45, n. 3, p. $236-243,2010$.

CRUZ, C. D. Genes: a software package for analysis in experimental statistics and quantitative genetics. Acta Scientiarum, v. 35, n. 3, p. 271-276,2017.

CRUZ, C. D.; FERREIRA, F. M.; PESSONI, L. A. Biometria aplicada ao estudo da diversidade genética. Viçosa, MG: UFV, 2011

DOYLE, J. J.; DOYLE, J. L. Isolation of plant DNA from fresh tissue. Focus, v. 12, n. 1, p. 13-15, 1990.

FERRÃO, R. G. et al. Genética e melhoramento: desenvolvimento e recomendação de cultivares com tolerância à seca para o Espírito Santo. Incaper em Revista, v. 6/7, n. 4, p. 51-71, 2016.

FISSEHA, Z. et al. Genetic diversity and population structure of common bean (Phaseolus vulgaris L.) germplasm of Ethiopia as revealed by microsatellite markers. African Journal Biotechnology, v. 15, n. 52, p. 2824-2847, 2016.

FOOD AND AGRICULTURE ORGANIZATION OF THE UNITED NATIONS. Colheitas. 2018. Disponível em: http:// www.fao.org/faostat/en/\#data/QC. Acesso em: 25 abril. 2018.

GAITÁN-SOLÍS, E. et al. Microsatéllite repeats in common bean (Phaseolus vulgaris): isolation, characterization, and cross-species amplification in Phaseolus ssp. Crop Science, v. 42, p. 2128-2136, 2002.

GEPTS, P. et al. Phaseolin-protein variability in wild forms and landraces of the common beans (Phaseolus vulgaris): evidence for multiple centers of domestication. Economic Botany, v. 40, n. 4, p. 451-468, 1986.

GOWER, J. C. A general coefficient of similarity and some of its properties. Biometrics, v. 27, n. 4, p. 857-874, 1971.

HAYAT, I. et al. Nutritional and health perspectives of beans (Phaseolus vulgaris L.): an overview. Critical Reviews in Food Science and Nutrition, v. 54, n. 5, p. 580-592, 2013. 
KELLER, B. et al. Fine-mapping of a major QTL controlling angular leaf spot resistance in common bean (Phaseolus vulgaris L.). Theoretical and Applied Genetics, v. 128, n. 5, p. 813-826, 2015.

MOJENA, R. Hierarchical grouping methods and stopping rules: an evaluation. The Computer Journal, v. 20, n. 4, p. 359-363, 1977.

NADEEM, M. A. et al. DNA molecular markers in plant breeding: current status and recent advancements in genomic selection and genome editing. Biotechnology \& Biotechnological Equipment, v. 32, n. 2, p. 261-285,2018.

RODRIGUES, T. B.; SANTOS, J. B. Effect of natural selection common bean (Phaseolus vulgaris L.) microsatellite alleles. Genetics and Molecular Biology, v. 29, n. 2, p. 345-352, 2006.

SILVA, A. R.; DIAS, C. T. S. A cophenetic correlation coefficient for Tocher's method. Pesquisa Agropecuária Brasileira, v. 48, p. 589-596, 2013.
SINGH, S. P.; GEPTS, P.; DEBOUCK, D. G. Races of common bean (Phaseolus vulgaris, Fabaceae). Economic Botany, v. 45, n. 3, p. 379-396, 1991.

SOKAL, R. R.; ROHLF, F. J. The comparison of dendrograms by objective methods. Taxon, v. 11, n. 2, p. 33-40, 1962.

VELOSO, J. S. et al. Genetic divergence of common bean cultivars. Genetics and Molecular Research, v. 14, n. 3, p. 11281-11291, 2015.

VIEIRA, M. L. C et al. Microsatellite markers: what they mean and why they are so useful. Genetics and Molecular Biology, v. 39, n. 3, p. 312-328, 2016.

$\mathrm{YU}, \mathrm{K}$. et al. Intrgration of simple sequence repeat (SSR) maker intro a molecular linkage map of commom bean (Phaseolus vulgaris L.). The Journal of Heredity, v. 91, n. 6, p. 429-434, 2000. 